\title{
Transition from Conventional Drugs to Promising Drugs for Primary Biliary Cholangitis
}

\author{
Kazufumi Dohmen* \\ Internal Medicine, Chihaya Hospital, Japan
}

Submission: March 09, 2017; Published: March 24, 2017

"Corresponding author: Kazufumi Dohmen, Internal Medicine, Chihaya Hospital, 2-30-1 Chihaya Higashi-ku,Fukuoka 813-8501, Japan, Tel: +81-92-661-2211; Fax: +81-92-683-0411; E-mail: dohmen-kzfm@cool.odn.ne.jp

\begin{abstract}
Primary biliary cholangitis (PBC), formerly known as primary biliary cirrhosis, is a chronic cholestatic liver disease characterized by chronic, non-suppurative, destructive cholangitis that eventually leads to cholestasis, fibrosis, cirrhosis and subsequent hepatic failure and death if left untreated. The only available therapeutic agent for PBC is ursodeoxycholic acid (UDCA), which has been demonstrated to delay the development of fibrosis as well as improve patient survival without the need for liver transplantation. However, not all patients achieve a complete biochemical response to UDCA.

Fibrate is a fibric acid derivative used in the treatment of hypercholesterolemia and hyperglyceridemia, and it has been incidentally noted to cause a decrease in serum liver biochemical markers. The proposed mechanism of action of fibric acid derivatives involves regulation of the expression of various kinds of lipids and proteins, as well as cell proliferation, through the activation of peroxisome proliferator-activated receptor- $\alpha$. Obeticholic acid, a first-in-class alternative farnesoid X receptor agonist, is a semi-synthetic bile acid analogue of $6 \alpha$-ethylchenodeoxycholic acid that is nearly 100 -fold more potent than chenodeoxycholic acid. The efficacy of both fibrate and beticholic acid in addition to UDCA in asymptomatic PBC patients who did not respond well to UDCA alone has been confirmed. Further progress in the study of newer drugs that are effective for symptomatic PBC patients is expected in the future.
\end{abstract}

Keywords: Primary biliary cholangitis; Fibrate; Histology; Therapy

\section{Ursodeoxycholic Acid}

The first known available therapeutic agent for primary biliary cholangitis (PBC) is ursodeoxycholic acid (UDCA), which has been demonstrated to delay the development of fibrosis as well as improve survival in patients without the need for liver transplantation [1-3]. The optimal dosage of UDCA is $13-15 \mathrm{mg} / \mathrm{kg} /$ day and it is the standardized treatment for PBC. However, not all patients achieve a complete biochemical response to UDCA, and 10$20 \%$ will progress to cirrhosis or require liver transplantation. The most important merits of UDCA are lower costs and few adverse effects.

\section{Budesonide}

Budesonide is a glucocorticoid receptor/pregnane $\mathrm{X}$ receptor (PXR) agonist. Combination therapy of budesonide and UDCA was able to ameliorate the plasma biochemical index of hepatic function and hepatic histology, particularly in PBC patients with hepatic fibrosis, whereas the treatment effeciveness of UDCA alone was principally seen in laboratory results [4].

\section{Methotrexate}

In patients who responded inadequately to UDCA, methotrexate noticeably improves hepatic enzyme tests and hepatic histology [5]. However, of the immunosuppressive drugs that have been tested for the treatment of PBC, azathioprine, cyclosporine and methotrexate were not found to improve patient survival $[6,7]$.

\section{Fibrates}

Fibrate is a fibric acid derivative used in the treatment of hypercholesterolemia and hyperglyceridemia that has been incidentally noted to cause a decrease in the levels of serum liver biochemical markers. The proposed mechanism of action of fibric acid derivatives involves the regulation of cell proliferation and the expression level of various lipids and proteins via the activation of peroxisome proliferator-activated receptor (PPAR)- $\alpha$ [8-10]. Therefore, fibric acid is referred to as a "PPAR- $\alpha$ agonist". Bezafibrate activates all three isoforms of human PPAR (PPAR- $\alpha$, PPAR- $\delta$, and PPAR- $\gamma$ ) at similar concentrations (i.e., 50, 20 and 60 
$\mu \mathrm{M}$, respectively) [11,12]. Therefore, the term "pan-PPAR" agonist is a more accurate description of bezafibrate. On the other hand, fenofibrate has been confirmed to exhibit a stronger binding activity for PPAR- $\alpha$ than bezafibrate [12]. Hence, fenofibrate is referred to as a "PPAR- $\alpha$-selective" agonist [11].

There are scarce data regarding the biochemical effects of fenofibrate in patients with PBC [11,13-19]. Moreover, the longterm biochemical effects of fenofibrate on $\mathrm{PBC}$ are unknown. As for histological studies of PBC patients treated with UDCA or UDCA plus fibrate, Angulo et al. [7] reported that long-term UDCA therapy for 6.5 years in 16 PBC patients resulted in eight cases of "no change/improvement" histologically and eight cases of "worse" findings, although the difference was not significant between the UDCA group and the control group (50\% vs. 71\%) [20]. In addition, Yano et al. reported that clear histological improvements were not observed in their study despite a dramatic biochemical response in patients treated with bezafibrate plus UDCA for PBC [21]. Recently, it was confirmed that the use of fenofibrate plus UDCA treatment for asymptomatic $\mathrm{PBC}$ leads to histological improvements as well as reductions in the levels of ALT, ALP, $\gamma$ GTP and IgM [22]. In the study, there was no apparent tendency for fenofibrate to cause elevation of the levels of total bilirubin, transaminase or creatinine. In addition, no patients experienced adverse effects, such as rhabdomyolysis, miosis or increased serum creatinine phosphokinase levels [22].

\section{Obeticholic Acid}

Obeticholic acid (OCA) is a semi-synthetic bile acid analogue of $6 \alpha$-ethyl-chenodeoxycholic acid that is nearly 100 -fold more potent than chenodeoxycholic acid (CDCA) and is a powerful firstin-class alternative FXR agonist derived from primary human bile acid CDCA, the natural endogenous FXR agonist. A randomized, controlled clinical trial showed that treatment with OCA observably decreased the serum concentrations of $\gamma$-GTP, ALP and ALT in PBC patients who had an inadequate response to UDCA, in comparison with placebo [23]. OCA is so expensive that improving costeffectiveness could be a challenge.

\section{Newer drug expectations and appropriate timing of administration of drugs}

The efficacy of UDCA, fibrate or other medicines for symptomatic PBC patients has not been confirmed. Newer drugs that are effective for symptomatic $\mathrm{PBC}$ patients are clearly needed. Moreover, the use of drugs is expected to be categorized according to the stage of PBC and response to drugs could be predictive of the outcomes of PBC.

\section{References}

1. Lindor KD, Jorgensen RA, Therneau TM, Malinchoc M, Dickson ER (1997) Ursodeoxycholic acid delays the onset of esophageal varices in primary biliary cirrhosis. Mayo Clin Proc 72(12): 1137-1140.

2. Poupon RE, Lindor KD, Cauch-Dudek K, Dickson ER, Poupon R, et al. (1997) Combined analysis of randomized controlled trials of ursodeoxycholic acid in primary biliary cirrhosis. Gastroenterology 113(3): 884-890.

3. Floreani A, Caroli D, Variola A, Rizzotto ER, Antoniazzi S, et al. (2011) A 35-year follow-up of a large cohort of patients with primary biliary cirrhosis seen at a single centre. Liver International 31(3): 361-368.

4. Rautiainen H, Kärkkäinen P, Karvonen AL, Nurmi H, Pikkarainen P, et al. (2005) Budesonide combined with UDCA to improve liver histology in primary biliary cirrhosis: a three-year randomized trial. Hepatology 41(4): 747-752.

5. Kaplan MM, Bonder A, Ruthazer R, Bonis PA (2010) Methotrexate in patients with primary biliary cirrhosis who respond incompletely to treatment with ursodeoxycholic acid. Dig Dis Sci 55(11): 3207-3217.

6. (1993) The results of randomized double blind controlled trial evaluating malotilate in primary biliary cirrhosis. A European multicentre study group. J Hepatol 17(2): 227-235.

7. Angulo $P$, Patel T, Jorgensen RA, Therneau TM, Lindor KD Silymarin in the treatment of patients with primary biliary cirrhosis with a suboptimal response to ursodeoxycholic acid. Hepatology 32(5): 897900.

8. Gebel T, Arand M, Oesch F (1992) Induction of the peroxisome proliferator-activated receptor by fenofibrate in rat liver. FEBS Lett 309(1): 37-40.

9. Schoonjans K, Staels B, Auwerx J (1996) Role of the peroxisome proliferator-activated receptor (PPAR) in mediating the effects of fibrates and fatty acids on gene expression. J Lipid Res 37: 907-925.

10. Honda A, Ikegami T, Nakamuta M, Miyazaki T, Iwamoto J (2013) Anticholestatic effects of bezafibrate in patients with primary biliary cirrhosis treated with ursodeoxycholic acid. Hepatology 57(5): 19311941.

11. Ghonem NS, Boyer JL (2013) Fibrates as adjuvant therapy for chronic cholestatic liver disease: Its time has come. Hepatology 57(5): 16911693.

12. Wilson TM, Brown PJ, Sternbach DD (2000) The PPAR- $\alpha$ : from orphan receptors to drug discovery. J Med Chem 43(4): 527-550.

13. Ohira H, Sato Y, Ueno T (2002) Fenofibrate treatment in patients with primary biliary cirrhosis. Am J Gastroenterol 97(8): 2147-2149.

14. Dohmen K, Mizuta T, Nakamuta M, Shimohashi N, Ishibashi H (2004) Fenofibrate for patients with asymptomatic primary biliary cirrhosis. World J Gastroenterol 10(6): 894-898.

15. Corpechot C, Abenavoli L, Rabahi N, Chrétien Y, Andréani T, et al. (2009) Comment on biochemical response to ursodeoxycholic acid and longterm prognosis in primary biliary cirrhosis. Hepatology 49(3): 337338.

16. Liberopoulos EN, Florentin M, Elisaf MS, Mikhailidis DP, Tsianos E (2010) Fenofibrate in primary biliary cirrhosis: a pilot study. Open Cardiovasc Med J 4: 120-126.

17. Levy C, Peter JA, Nelson DR, Keach J, Petz J, et al. (2011) Pilot study: fenofibrate for patients with primary biliary cirrhosis and an incomplete response to ursodeoxycholic acid. Aliment Pharmacol Ther 33(2): 235-242.

18. Han XF, Wang QX, Liu Y, You ZR, Bian ZL, et al. (2012) Efficacy of fenofibrate in Chinese patients with primary biliary cirrhosis partially responding to ursodeocycholic acid therapy. J Dig Dis 13(4): 219-224.

19. Dohmen K, Tanaka H, Haruno M (2013) The effectiveness of fenofibrate in comparison to bezafibrate for patients with asymptomatic primary biliary cirrhosis. Fukuoka Acta Medica 104(10): 350-361.

20. Angulo P, Batts KP, Therneau TM, Jorgensen RA, Dickson ER, et al. (1999) Long-term ursodeoxycholic acid delays histological progression in primary biliary cirrhosis. Hepatology 29(3): 644-647.

21. Yano K, Kato H, Morita S, Takahara O, Ishibashi H, et al. (2002) Is bezafibrate histologically effective for primary biliary cirrhosis? Am J Gastroenterol 97(4): 1075-1077. 
22. Dohmen K, Tanaka T, Haruno M (2016) Biochemical and histologica effectiveness of long-term use of fenofibrate for asymptomatic primary biliary cholangitis. J GHR 5: 2125-2131
23. Hirschfield GM, Mason A, Luketic V, Lindor K, Gordon SC, et al. (2015) Efficacy of obeticholic acid in patients with primary biliary cirrhosis and inadequate response to ursodeoxycholic acid. Gastroenterology 148: 751-761.

\section{Your next submission with Juniper Publishers will reach you the below assets}

- Quality Editorial service

- Swift Peer Review

- Reprints availability

- E-prints Service

- Manuscript Podcast for convenient understanding

- Global attainment for your research

- Manuscript accessibility in different formats ( Pdf, E-pub, Full Text, Audio)

- Unceasing customer service

Track the below URL for one-step submission https://juniperpublishers.com/online-submission.php 